\title{
ANALISIS RASIO LIKUIDITAS, RASIO SOLVABILITAS, DANUNDERWRITING RATIO UNTUK MENGUKUR KINERJA KEUANGAN PT MANDIRIAXA GENERAL INSURANCE DI INDONESIA PASCA OJK (OTORITAS JASA KEUANGAN)
}

\author{
Putri Kurnia Widiati \\ Esy Nur Aisyah \\ Fakultas Ekonomi Universitas Islam Negeri Maulana Malik Ibrahim Malang \\ Jl. Gajayana No. 50 Malang, Telepon/Fax. (0341) 558881 \\ kurniawidiatiputri@gmail.com; esynuraisyah@yahoo.com
}

\begin{abstract}
This study aimstoanalyzethe development ofthe financial performance of PT Mandiri AXAGeneral Insurance in Indonesia after the establishment of the FSA (Financial Services Authority) in 2013 by using the analysis of liquidity ratios, solvency ratios using solvabillitas rate calculation and risk-based minimum capital, and undderwiting ratio. Based on the results it can be concluded that penellitian seen from the calculation of the solvency ratiousing solvabillitas level of risk-based andminimum capital ratio under wrting result and showed unfavorable results, while the liquidity ratio has increase devery year. The results of the calculation of this ratio in dicates poor performance (except for the liquidity ratio) associated with the presence of FSA (Financial Services Authority).
\end{abstract}

Keywords: liquidity ratio, solvency ratio, and underwriting ratio

Salah satu alat yang digunakan untuk mengetahui kondisi keuangan perusahaan dapat berwujud laporan keuangan. Laporan keuangan menyajikan gambaran mengenai posisi keuangan dari kinerja perusahaan dalam menghasilkan laba. Posisi keuangan perusahaan ditujukan dalam laporan neraca, dalam laporan neraca kita dapat mengetahui kekayaan atau aset perusahaan yang dimiliki (sisi aktiva), dan dari sisi pasiva dapat kita ketahui asal dana untuk membiayai aktiva tersebut (dari modal sendiri atau hutang), sedangkan kinerja perusahaan dalam laporan keuangan meruakan proses yang penuh pertimbangan dalam rangka membantu mengevaluasi posisi keuangan dan hasil operasi perusahaan pada masa sekarang dan masa lalu, dengan tujuan untuk menentukan eliminasi dan prediksi mengenai kondisi dan kinerja perusahaan pada masa mendatang. Berkaitan dengan proses evaluasi kinerja, pada penelitian ini mengambil objek salah satu lembaga keuangan non bank (asuransi) dan kaitannya dengan evaluasi kinerja oleh OJK (Otoritas Jasa Keuangan) dimana OJK melaksanakan tugasnya untuk mengevaluasi lembaga keuagan non bank terhitung sejak awal tahun 2013 (UU No 21 tahun 2011). Menurut pasal 9 UU No 21 tahun 2011 salah satunya menyebutkan bahwa wewenang OJK adalah melakukan pengawasan, pemeriksaan, penyidikan, perlindungan konsumen dan tindakan lain terhadap
Lembaga Jasa Keuangan, hal ini dalam perkembagannya OJK dapat menarik biaya jasa pengawasan terhadap lembaga keuangan. Hal ini dapat mempengaruhi kinerja keuangan perusahaan lembaga keuangan yang bersangkutan. Oleh karena itu peneliti disini melakukan penelitian mengenai dampak adanya OJK terhadap kinerja keuangan perusahaan lembaga keuangan. Dan bagaimana kinerja keuangan PT Mandiri Axa General Insurance pasca OJK ditinjau dari rasio likuiditas, rasio solvabilitas, dan rasio underwrting?

Alat analisa yang digunakan oleh peneliti adalah rasio solvabilitas, rasio likuiditas, dan rasio underwriting. Analisis rasio keuangan adalah perbandingan antara dua atau kelompok data laporan keuangan dalam suatu periode tertentu, data tersebut dapat merupakan data dari neraca dan data laporan rugi laba. Tujuannya adalah memberikan gambaran mengenai kelemahan dan kemampuan finansial perusahaan dari tahun ke tahun. Analisis rasio ini akan sangat membantu dalam menilai prestasi manajemen di masa lalu dan prospeknya di masa yang akan datang. Pada dasarnya ada beberapa rasio keuangan yang biasa digunakan yaitu rasio likuiditas, rasio solvabilitas, rasio keuntungan/profitabilitas, rasio leverage, rasio aktivitas dan rasio penilaian (Sutrisno, 2009:215).

Berdasarkan latar belakang di atas, penelitian ini bertujuan untuk mengetahui kinerja keuangan PT 
Mandiri Axa General Isurance pasca OJK dalam memenuhi semua kewajibannya dengan menggunakan membayar kewajiban jangka pendeknya dengan rasio likuiditas, rasio solvabilitas, dan rasio underwriting.

\section{RASIO KEUANGAN}

Dennis (2006) menyatakan bahwa analisis rasio keuangan merupakan metode yang paling baik digunakan untuk memperoleh gambaran kondisi keuangan perusahaan secara keseluruhan. Menurut Usman (2003), analisis ini berguna sebagai analisis intern bagi manajemen perusahaan untuk mengetahui hasil keuangan yang telah dicapai guna perencanaan yang akan datang dan juga untuk analisis intern bagi kreditur dan investor untuk menentukan kebijakan.

Menurut Gill dan Moira (2002), rasio adalah memperbandingkan suatu hal dengan hal lainnya sehingga dapat menunjukan hubungan atau korelasi. Rasio keuangan merupakan suatu cara yang membuat perbandingan data keuangan perusahaan menjadi lebih berarti termasuk pemberian kredit dan penanaman modal suatu perusahaan.

Rasio likuiditas menurut Sutrisno (2009:215) adalah kemampuan perusahaan untuk membayar kewajibannya yang harus segera dipenuhi. Sedangkan menurut munawir (2007:31) adalah rasio yang menunjukkan kemampuan suatu perusahaan untuk memenuhi kewajiban keuangannya yang segera harus dipenuhi, atau kemampuan perusahaan untuk memenuhi kewajiban jangka pendeknya. Menurut munawir (2004), rasio likuiditas dapat dibagi menjadi tiga: (1) Current Ratio $(C R)$ yaitu perbandingan antara aktiva lancar dan hutang lancar. (2) Quick Ratio( $Q R$ ) yaitu perbandingan antara aktiva lancar dikurangi persediaan terhadap hutang lancardan (3) Working Capital to Total Asset (WCTA) yaitu perbandingan antara aktiva lancar dikurangi hutang lancar terhadap jumlah aktiva.

Menurut Robert Ang (1997) rasio solvabilitas menunjukkan kemampuan perusahaan untuk memenuhi kewajiban jangka panjangnya. Rasio ini juga disebut leverage ratios, karena merupakan rasio pengungkit yaitu menggunakan uang pinjaman (debt) untuk memperoleh keuntungan. Sedangkan rasio likuiditas menyatakan kemampuan perusahaan jangka pendek untuk memenuhi obligasi (kewajiban) yang jatuh tempo. Rasio ini dapat diproksikan dengan (1) Debt Ratio $(D R)$ yaitu perbandingan antara total hutang dengan total asset, (2) Debt to Equity Ratio (DER) yaitu perbandingan antara jumlah hutang lancar dan hutang jangka panjang terhadap modal sendiri, (3) Long Term Debt to Equity Ratio (LTDER) yaitu perbandingan antara jumlah hutang lancar dan hutang jangka panjang terhadap modal sendiridan (4) Time Interest Earned (TIE) yaitu perbandingan antara pendapatan sebelum pajak terhadap bunga hutang jangka panjang.

Rasio underwriting merupakan penentu pokok dari posisi laba usaha perusahaan asuransi. Peningkatan keuntungan usaha asuransi tersebut sebagai usaha utama perusahaan. Selain itu rasio underwriting merupakan rasio keuangan yang dibuat berdasarkan informasi dari laporan keuangan perusahaan dan bertujuan untuk memudahkan melakukan identifikasi terhadap halhal penting yang berkaitan dengan kinerja keuangan perusahaan. (Munawir, 2007:82).

\section{Kerangka Pikir}

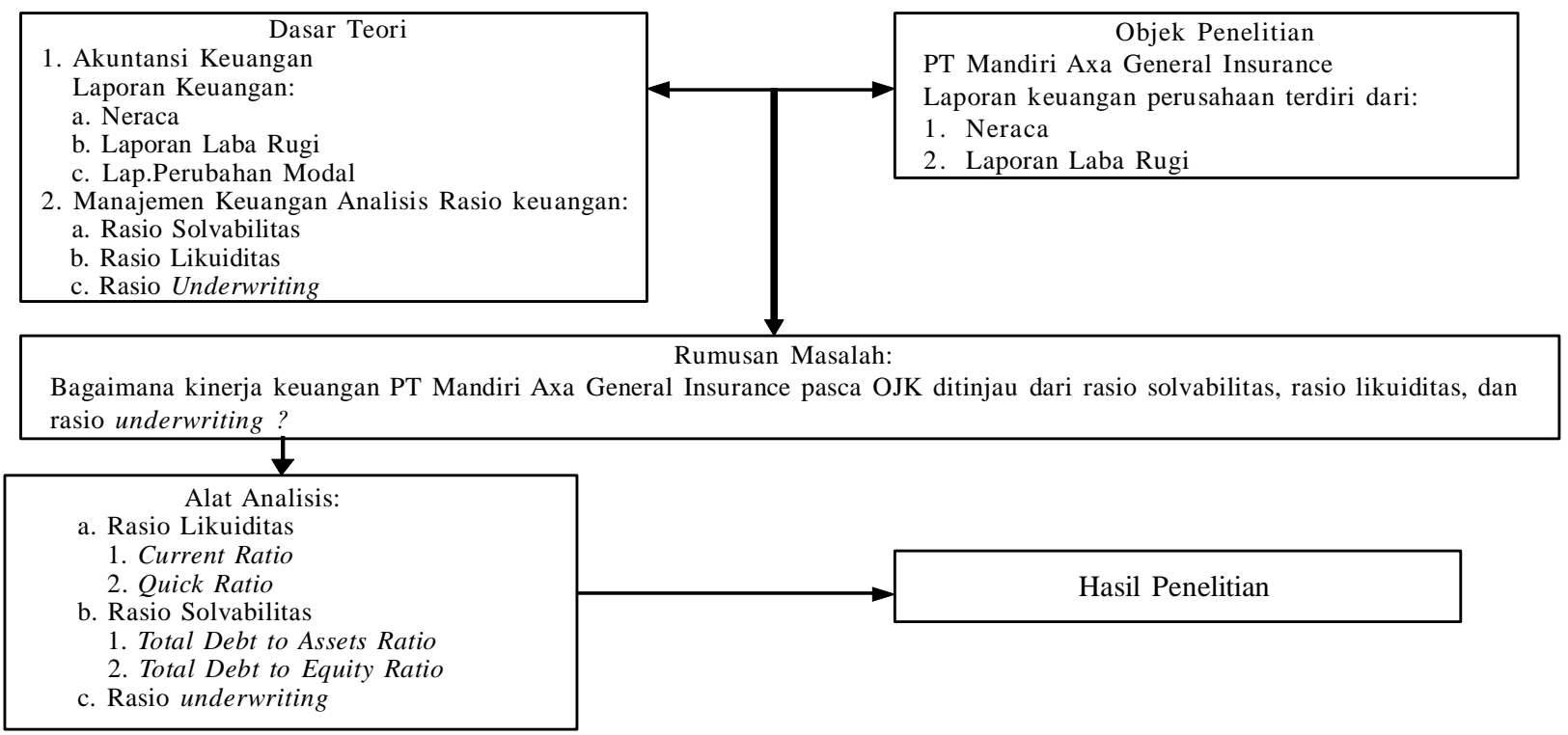




\section{METODE}

\section{Definisi Operasional}

Untuk memberikan penjelasan mengenai indikator yang digunakan dalam penelitian dan usaha pemecahan masalah sesuai dengan judul penelitian ini, maka dirumuskan mengenaidefinisi operasional yang dapat dijabarkan sebagai berikut: (1) PT Mandiri AXA General Insurance yang merupakan perusahaan yang bergerakdibidang asuransi; (2) Laporan keuangan PT Mandiri AXA General Insurance adalah hasil akhir proses akuntansiyang memberikan informasi posisi keuangan dan hasil usaha (kinerja) PT Mandiri AXA General Insurance yang meliputi Neraca dan Laporan Laba Rugi. Neraca merupakan laporan keuangan yang menggambarkan posisi keuangan PT Mandiri AXA General Insurance pada waktu tertentu yang terdiri dari dua bagian yaitu kelompok aktiva dan kelompok kewajiban ditambah ekuitas. Laporan Laba Rugi merupakan laporan keuangan yang menggambarkan hasil usaha PT Mandiri AXA General Insurance selama satu periode tertentu; (3) Analisis laporan keuangan adalah perhitungan rasio-rasio untuk menilai keadaan keuangan PT Mandiri AXA General Insurance untuk tahun 2012, 2013, dan 2014; (4) Rasio keuangan adalah angka yang diperoleh dari hasil perbandingan dari satu pos laporan dengan pos lainnya yang mempunyai hubungan yang relevan dan signifikan untuk menunjukkan kinerja keuangan pada PT Mandiri AXA General Insurance pada tahun 2012, 2013 dan 2014; (5) Rasio likuiditas adalah rasio yang digunakan untuk mengukur kemampuan PT Mandiri AXA General Insurance tahun 2012, 2013, dan 2014 dalam membayar semua kewajiban keuangan jangka pendek pada saat jatuh tempo dengan menggunakan aktiva lancar yang tersedia; (6) Rasio solvabilitas adalah rasio yang mengukur seberapa besar kemampuan PT Mandiri AXA General Insurance tahun 2012, 2013 dan 2014 dalam memenuhi semuakewajibannya apabila perusahaan dilikuidasi.

\section{Alat Analisis}

Dalam menganalisa data, penulis menggunakan teknik penelitian dengan metode komparatif, yaitu dengan cara membandingkan laporan-laporan keuangan tiga periode berturut-turut dengan menguraikan faktor-faktor yang mempengaruhi posisi keuangan. Sedangkan metode penelitian yang digunakan adalah metode deskriptif analitis, yaitu metode yang berusaha mengumpulkan data yang sesuai dengan keadaan yang sebenarnya, menyajikan dan menganalisisnya sehingga dapat memberikan perbandingan yang cukup jelas mengenai objek yang diteliti yang kemudian dapat ditarik suatu kesimpulan dan data tersebut dianalisis dengan menggunakan analisis rasio. Adapun analisis yang digunakan yaitu rasio likuiditas, rasio solvabilitas dan rasio underwriting. Rumus dalam menghitung rasio tersebut menurut Sutrisno (2009:215-227):

Rasio Solvabilitas $=$ Total hutang $\mathrm{x} 100 \%$ Total aktiva

Rasio Likuiditas $=\underline{\text { Aktiva Lancar } \mathrm{x} \text { 100\% }}$ Hutang lanccar

Rasio Underwriting $=\underline{\text { Jumlah kewajiban x } 100 \%}$ Total kekayaan

\section{HASIL DAN PEMBAHASAN}

\section{Analisis Masalah}

Penelitian ini dilakukan pada PT Mandiri AXA General Insurance Indonesia. Asuransi PT Mandiri AXA General Insurance Indonesia adalah perusahaan yang bergerak di bidang pelayanan jasa asuransi dengan menyediakan berbagai jenis produk asuransi. Penelitian ini bertujuan untuk mengetahui bagaimana kinerja keuangan PT Mandiri AXA General Insurance Indonesia ditinjau dari rasio keuangan berupa rasio likuiditas, rasio solvabilitas, dan rasio underwriting. Pada bab ini penulis akan melakukan analisis terhadap laporan keuangan yang terdiri dari laporan neraca dan laporan laba rugi untuk periode tahun 2012, 2013 dan 2014. Untuk mengetahui dan memperoleh gambaran tentang pengukuran kinerja keuangan suatu perusahaan maka diperlukan analisis terhadap laporan keuangan. Pengukuran kinerja keuangan berdasarkan rasio bertujuan agar dapat mengelola keuangan dengan baik dan mengendalikan jalannya kegiatan operasional perusahaan asuransi secara lebih efektif. Dengan menganalisis laporan keuangan akan didapat seberapa besar kinerja keuangan yang dihasilkan telah memenuhi standar tingkat batas yang ditetapkan, sehingga hasil yang dicapai dapat menilai tingkat kesehatan perusahaan asuransi tersebut.

Sesuai dengan perumusan masalah sebagai pedoman dalam analisis terhadap permasalahan, penulis akan mencoba untuk mengkaji permasalahanpermasalahan tersebut. Berdasarkan masalah pokok yang dihadapi perusahaan adalah laporan keuangan yang menunjukkan kondisi keuangan perusahaan cenderung stabil. Perkembangan keuangan perusahaan yang mengalami kenaikan secara signifikan. Meskipun PT Mandiri AXA General Insurance Indonesia menunjukkan laporan keuangan yang cukup 
baik pasca OJK, hendaknya tetap dilakukan perencanaan dan pengawasan terhadap kinerja keuangan perusahaan di setiap tahunnya.

Permasalahan yang akan dibahas sesuai batasan masalah adalah membatasi analisis pada kinerja keuangan berdasarkan rasio keuangan sesuai data yang disajikan pada laporan keuangan perusahaan asuransi. Dalam melakukan analisa terhadap kinerja keuangan yang dihasilkan oleh perusahaan, maka penulis menggunakan laporan keuangan periode tiga tahun untuk menghitung nilai rasio keuangan, yang kesimpulannya akan menunjukkan perolehan tingkat batas sebagai perbandingan standar kesehatan perusahaan tersebut.

\section{Analisis Rasio Keuangan Solvabilitas}

Rasio solvabilitas menekankan pada jumlah modal yang dapat melindungi kelebihan penerimaan premi dari pengaruh yang tidak menguntungkan. Rasio ini sangat penting bagi pemilik perusahaan. Berikut ini tabel perhitungan rasio keuangan solvabilitas PT Mandiri AXA General Insurance:

Tabel 1. Perhitungan Rasio Solvabilitas PT Mandiri AXA General Insurance

\begin{tabular}{cccc}
\hline Keterangan & $\mathbf{2 0 1 2}$ & $\mathbf{2 0 1 3}$ & $\mathbf{2 0 1 4}$ (Tri wulan I) \\
\hline Rasio Solvabilitas & $127 \%$ & $445 \%$ & $523 \%$ \\
\hline
\end{tabular}

Sumber: data diolah 2014

Dari tabel di atas menunjukkan bahwa jumlah modal yang dihasilkan oleh perusahaan meliputi dana pemegang saham semakin meningkat dan menandakan menurunnya kemampuan keuangan perusahaan dalam menunjang kewajiban yang mungkin timbul dari penutupan risiko. Premi yang merupakan pendapatan murni dari usaha asuransi menjadi bagian dalam perkembangan keuangan perusahaan asuransi yang tercermin dari pendapatan premi. Meskipun masih terdapat kenaikan premi neto, hal ini mengindikasikan meningkatnya ketidaksiapan perusahaan ketika menghadapi pertumbuhan premi yang tinggi. Ketidakstabilan rasio solvabilitas ini disebabkan karena PT Mandiri AXA General Insurance belum terampil didalam mengontrol jumlah modal pemegang saham (stockholder) yang dimiliki oleh perusahaan. Semakin tinggi nilai yang dihasilkan, maka semakin baik dalam meningkatkan dana kekayaan kedudukan pemegang saham. Hal ini didukung jumlah modal lebih besar daripada premi neto yang berasal dari tertanggung, agen atau reasuradur. Setiap perusahaan asuransi memiliki prospek pertumbuhan keuangan yang berbeda, karenanya meskipun nilai modal yang dihasilkan rendah tidak selalu berarti bahwa perusahaan tersebut undervalued. Nilai modal yang rendah dapat disebabkan karena laba perusahaan asuransi yang bersangkutan tidak mengalami pertumbuhan keuangan, mengalami perlambatan pertumbuhan keuangan atau bahkan mengalami kesulitan finansial.

Dalam hal ini berarti kenaikan pada PT Mandiri AXA General Insurance adalah mengalami perlambatan pertumbuhan keuangan yang disebabkan kondisi keuangan setiap tahunmenunjukkan penurunan, menjadikan nilai modal yang telah dikumpulkan dinilai belum cukup mengimbangi lajunya premi netto yang dihasilkan. Hubungan antara modal denganpremi netto adalah tingkat pendapatan atau income usaha asuransi yang dananya berasal dariperbedaan kepemilikan tetapi bersama-sama memiliki kepentingan dalam menghasilkankeuntungan bagi perusahaan.

Kerugian dari pengaruh premi yang tidak menguntungkan mengakibatkan beberapa hal seperti penerapan tingkat premi yang sedemikian rendah menyebabkan tidak sebanding dengan manfaat yang diperjanjikan dalam polis asuransi, penerapan tingkat premi yang berlebihan menyebabkan rusaknya kompetisi underwriting yang sehat antar perusahaan asuransi, dan penerapan tingkat premi mempunyai nilai bersifat diskriminatif apabila tertanggung dengan luas penutupan asuransi serta tingkat risiko yang sama dikenakan tingkat premi yang berbeda.

Pemberlakuan pada PT Mandiri AXA General Insurance di sini adalah penerapan tingkat premi yang tinggi dibandingkan dengan perusahaan asuransi lain, yang mengakibatkan ketidakstabilannya premi netto yang diterima. Kondisi yang harus disiapkan sebagai faktor pemicu keberhasilan implementasi dalam rasio solvabilitas yaitu: (1) Komitmen dari manajemen keuangan untuk mencapai target kinerja keuangan yang baik dengan melihat pertumbuhan keuangan dari hasil laba yang diperoleh dan pengembangan asset-asset yang dimilikinya, (2) Fokus penempatan modal pada perusahaan karena biasanya pemegang saham (stockholder) ingin mengetahui return (tingkat pengembalian) yang diperoleh pemilik perusahaan atas modal yang diinvestasikan, (3) Pemanfaatan pengaruh peranan nasabah yang masih tetap mempercayakan dananya disimpan di perusahaan asuransi yang bersangkutan dan (4) Kemandirian perusahaan dalam mengurangi peranan reasuransi sebagai pertanggungan ulang terhadap risiko yang dihadapi oleh perusahaan asuransi. 


\section{Analisis Rasio Keuangan Likuiditas}

Rasio likuiditas menunjukkan seberapa besar jumlah kewajiban yang mampu dipenuhi oleh perusahaan dari penggunaan seluruh kekayaan yang diperkenankan. Berdasarkan Peraturan Menteri Keuangan No.11/PMK.010/2011 mengenai kekayaan yang diperkenankan (admitted assets) maka untuk menghitung jenis kekayaan tersebut sebelum dilakukan pengukuran kinerja keuangan berdasarkan rasio likuiditas dapat dilihat pada Tabel 2 berikut:

Tabel 2. Perhitungan Rasio Likuiditas PT Mandiri AXA General Insurance

\begin{tabular}{lrrc}
\hline KETERANGAN & $\mathbf{2 0 1 2}$ & $\mathbf{2 0 1 3}$ & $\mathbf{2 0 1 4}$ (Tri wulan I) \\
\hline Rasio Likuiditas & $108 \%$ & $146 \%$ & $153 \%$ \\
\hline
\end{tabular}

Sumber: data diolah 2014

Dari perhitungan pada tabel 2 di atas, dapat diketahui bahwa jumlah kewajiban dan total kekayaan yang diperkenankan setiap tahun terjadi kenaikan. Hal ini menunjukkan bahwa dalam pemenuhan kewajiban perusahaan termasuk piutang premi dan piutang reasuransi tidak perlu dikhawatirkan lagi, karena besarnya asset yang dimiliki oleh PT Mandiri AXA General Insurance. Hal ini menunjukkan bahwa perhatian yang cukup serius atas hak penagihan atau piutang kepada tertanggung, agen dan reasuradur dapat teratasi atau di manage dengan cara seefisien mungkin. Misalnya dalam hal perusahaan memberikan diskon premi kepada tertanggung atau agen, maka diskon tersebut langsung dikurangkan dari piutang preminya. Demikian juga dalam hal terdapat uang muka pembayaran klaim dari atau ke pihak reasuradur (cash loss), maka jumlah tersebut langsung dikurangkan dalam piutang reasuransinya. Di samping itu, investasi pada PT Mandiri AXAGeneral Insurance yang merupakan sumber dana atas penghasilan danadana yang belum digunakan atau idle cash dapat digunakan untuk pengeluaran yang tidak terduga, sehingga dengan demikian mengurangi risiko "krisis likuiditas". Bilamana perusahaan menyadari bahwa jumlah investasi yang dimilikinya sudah besar maka akan diambil sebagian untuk ditanamkan dalam jenis investasi yang dapat memberikan penghasilan kepada perusahaan asuransi dalam bentuk bunga.

Berkaitan dengan bunga, hal tersebut juga dapat terlihat dari janji untuk membayar dikemudian hari, yang dalam arti bahwa janji itu terkandung suatu kesanggupan untuk mengembangkan dana (premi) yang diterima dari masyarakat. Misalnya dalam menetapkan tingkat premi telah diperhitungkannya unsur bunga yang akan dibayarkan kepada tertanggung atau pemegang polis pada saat terjadi klaim. Dengan demikian, sudah teroptimalnya taksiran pada hutang klaim yang dihasilkan oleh perusahaan. Adapun pada hutang reasuransi yang mengalami penurunan setiap tahun disebabkan karena adanya pembayaran hutang reasuransi tersebut.

Sejalan dengan karakteristik usaha asuransi, PT Mandiri AXA General Insurance telah mengikuti ketentuan perundangan yang berlaku saat ini bahwa perusahaan asuransi bukan hanya didorong untuk melakukan invested assets yang aman dan menguntungkan melainkan juga agar dalam melakukan investasi terdapat diversifikasi. Untuk itu pengaturan diversifikasi dibagi menjadi jenis investasi yang termasuk dalam jenis kekayaan yang diperkenankan. Berdasarkan pengalaman dalam kehidupan sehari-hari, PT Mandiri AXA General Insurance menghindari pengelolaan keuangan seperti hutang jangka panjang yang dikaitkan dengan tingginya risiko tingkat bunga. Apabila tingkat bunga pada masa mendatang diperkirakan akan meningkat, maka pihak kreditur akan mengenakan beban bunga yang tinggi. Hal ini mendasari PT Asuransi Central Asia Cabang Palembang untuk berasumsi bahwa semakin lama jangka waktu hutang tersebut, maka akan semakin besar ketidakpastian untuk dapat melunaskannya. Hutang jangka panjang yang dimaksud seperti hutang obligasi, kredit investasi dan hutang hipotik.

\section{Analisis Rasio Keuangan Underwriting}

Rasio underwriting merupakan penentu pokok dari posisi laba usaha perusahaan asuransi. Peningkatan keuntungan usaha asuransi tersebut sebagai usaha utama perusahaan.Untuk menghitung seberapa besar hasil underwriting diatas pendapatan premi, maka dapat dilihat pada tabel 3 berikut ini:

Tabel 3. Perhitungan Rasio Underwriting PT Mandiri AXA General Insurance

\begin{tabular}{lccc}
\hline KETERANGAN & $\mathbf{2 0 1 2}$ & $\mathbf{2 0 1 3}$ & $\mathbf{2 0 1 4}$ (Tri wulan I) \\
\hline Rasio Solvabilitas & $16,6 \%$ & $27 \%$ & $28,9 \%$ \\
\hline
\end{tabular}

Sumber: data diolah 2014

Pendapatan premi adalah sejumlah uang yang dihimpun dari nasabah yang memiliki atau membeli polis asuransi dari perusahaan asuransi. Dari perhitungan pada tabel 3 di atas, dapat diketahui bahwa pendapatan premi setiap tahun terjadi penurunan. Hal 
ini menunjukkan bahwa hasil underwriting yang dihasilkan oleh perusahaan belum mampu dalam mengalami proses underwriting sehingga jumlah beban yang dimiliki cukup besar dapat mengurangi laba perusahaan. Seiring bertambahnya tahun mengakibatkan kondisi keuangan perusahaan pada pendapatan premi untuk tahun 2012-2014 menjadi kurang baik Padahal dari pendapatan premi inilah suatu perusahaan asuransi memperoleh keuntungan. Keuntungan inilah yang digunakan untuk menjalankan kegiatan operasional perusahaan sehari-hari. Meskipun nilai rasio underwriting menunjukkan tingkat batas yang kurang sehat tetapi setidaknya PT Mandiri AXA General Insurance mulai menunjukkan kemampuannya dalam misi menciptakan perusahaan asuransi yang sehat, di mana peranan perusahaan untuk meningkatkan pelayanan underwriting harus selalu diupayakan. Dokumen dasar dalam melakukan suatu pertanggungan adalah surat permohonan tertulis atau aplikasi yang diajukan tertanggung kepada perusahaan asuransi disebut dengan formulir pengajuan asuransi. Di dalam formulir tersebut memuat ketentuan informasi lengkap antara lain mengenai jenis produk asuransi, tarif premi yang dikenakan, jumlah premi yang akan dibayar, dan informasi lainnya mengenai timbulnya kerugian. Ketentuan informasi inilah bagi perusahaan asuransi digunakan untuk tujuan underwriting dan indentifikasi klaim.

Faktor penyebab belum tercapainya tingkat batas yang diharapkan sesuai dengan tingkat kesehatan perusahaan asuransi, jika dilihat dari kekurangan PT Mandiri AXA General Insurance adalah ketidakmampuan dalam memaksimalkan laba melalui penentuan seleksi risiko yang diperkirakan akan mendatangkan laba bersih bagi perusahaan. Tanpa underwriting yang cermat, perusahaan asuransi tidak mampu bersaing karena dalam prakteknya untuk menarik nasabah harus ada ketelitian mengenai risiko yang baik dan risiko yang kurang menguntungkan dalam obyek yang diasuransikan, sesuai dengan informasi data yang diperoleh. Di samping itu, masih bertumpunya fungsi pemasaran dalam penjualan polisasuransi yang menekan biaya komisi.

Upaya yang dilakukan oleh PT Mandiri AXA General Insurance dalam menstabilkan tingkat keuntungan dari usaha asuransi adalah menghindari pertanggungan yang melebihi batas kemampuan (own retention) asuransi tersebut, baik dari harga pertanggungan maupun tingkat atau kualitas resikonya (degree quality of risk). Hal ini perlu dilakukan karena mengingat adanya pengelolaan keuangan perusahaan asuransi yang merupakan pengelolaan dana hasil underwriting akan menentukan seberapa besar tingkat pertumbuhan dan pencapaian laba bersih yang dihasilkan oleh perusahaan. Namun keberhasilan ini kurang memiliki arti apabila tingkat hasil underwriting yang dapat diperoleh tidak dikelola secara optimal.

Lebih lanjut dikatakan bahwa hasil underwriting sebagai hasil yang didapat atas kegiatan operasional perusahaan asuransi meliputi komponen berupa pendapatan underwriting (premi) dan beban underwriting (beban klaim dan beban komisi). Dengan kata lain, diharapkan PT Mandiri AXA General Insurance agar lebih bisa mengoptimalkan kegiatan operasionalnya melalui perkiraan seleksi resiko yang tepat dilakukan oleh bagianunderwriting, untuk kegiatan pemasaran produk asuransi tidak bergantung kepada agen atau broker sehingga dapat menghasilkan keuntungan yang maksimal bagi perusahaan.

\section{KESIMPULAN}

Berdasarkan analisis rasio yang telah dilakukan mengenai Analisis Kinerja Keuangan pada PT Mandiri AXA General Insurance untuk tahun 20122014, maka dapat ditarik beberapa simpulan yaitu pertama, perhitungan rasio likuiditas selama tiga tahun secara keseluruhan menunjukkan kelompok yang termasuk sehat karena rata-rata tingkat batas rasio tersebut mengalami peningkatan dari tahun ke tahun. Hal ini disebabkan karena pengendalian efisiensi baik hutang-piutang yang dapat dikelola dengan baik oleh perusahaan. Selain itu, pemanfaatan dari jumlah investasi yang dimiliki terealisasi sebagian sebagai simpanan yang nantinya dapat digunakan sebagai pengalihan apabila perusahaan mengalami krisis likuiditas. Demikian juga, dalam tindakan prinsip kehati-hatian seperti hutang jangka panjang tidak diperlukan bagi perusahaan dikarenakan risiko tingkat bunga yang tinggi.

Kedua, perhitungan rasio solvabilitas selama tiga tahun secara keseluruhan menunjukkan kelompok yang termasuk tidak sehat karena rata-rata tingkat batas rasio tersebut belum berada diatas $120 \%$. Hal ini disebabkan karena kurangnya pengalaman sumber daya manusia mengenai pemanfaatan modal perusahaan ditambah juga penerapan pada tingkat premi yang rendah menyebabkan dampak yang berpengaruh besar karena pendapatan premi yang dihasilkan tidak dirasakan manfaatnya bagi perusahaan.

Ketiga, perhitungan rasio underwriting selama tiga tahun secara keseluruhan menunjukkan kelompok yang termasuk tidak sehat karena rata-rata tingkat 
batas rasio tersebut berada di bawah $40 \%$. Hal ini disebabkan karena kurangnya kemampuan bagian underwriting dalam menentukan seleksi risiko dan ditambah dengan ketergantungan perusahaan untuk menjual polis asuransinya kepada agen atau broker.

Keempat, perhitungan rasio solvabilitas dan rasio underwriting yang menunjukkan hasil tidak stabil ini menunjukkan adanya pengaruh OJK yang dapat mengambil pungutan kepada lembaga keuangan yang diperiksanya (UU No 21 tahun 2011 mengenai OJK pasal 34), sehingga hal ini dapat menyebabkan conflict of interest serta dapat mendorong semakin tingginya biaya operasional perusahaan dan bermuara terhadap peningkatan lending-cost bagi perusahaan secara keseluruhan dampak lain juga dapat menghambat pemberdayaan perekonomian nasional.

\section{DAFTAR RUJUKAN}

Ang, R. 1997. BukuPintarPasar Modal Indonesia. Jakarta: Mediasoft Indonesia.

Bahtiar, U. 2003. "Analisis Rasio Keuangan dalam Memprediksi Perubahan Laba pada Bank-Bank di Indonesia”. Media Riset Bisnis dan Manajemen. Vol 3. No 1 April, 2003. PP 59-74.
Batunanggar. 2006. Jaring Pemgaman Sistem Keuangan: Kajian Literatur dan Prakteknya di Indonesia. Jakarta: Bank Indonesia.

Batunanggar, S. 2002. Redisigning Indonesia s Crisis Management: Deposit Insurance and Lender of Last Resort. Financial Stability Review. Jakarta: Bank Indonesia.

Batunanggar, S. 2004. Indonesia s Banking Crisis Resolution: Prosess, Issues and Lessons.

C.A.E. Goodhart. The changing role of central banks. BIS workpaper. Basel, Swiss. November 2010.

Gill, James, O., \& Moira, C. 2002. Dasar-Dasar Analisis Laporan Keuangan. Penerjemah: EkaHerawati. Jakarta: PPM.

Learnt. Financial Stability Review. May. Bank Indonesia. Munawir. 2007. Analisa Laporan Keuangan Perusahaan Asuransi. Cetakan Kedua. Yogyakarta: Liberty.

Richard, D., \& Kai, L., \& Ulf Soderstorm. 2006. ’Monetary Policy in Small Open Economy Preference for Robustness". Working paper316. IGIER (Innocenzo Gasparini Innstitute for Economic Research). Bocconi University.

Sutrisno. 2009. Manajemen Keuangan Teori, Konsep dan Aplikasi. Yogyakarta: Ekonisia.

UU No. 21 tahun 2011 tentang Otoritas Jasa Keuangan.

UU No. 23 th 1999 sebagaimana diubah dengan UU No 3 th 2004 tentang Bank Indonesia.

UU No. 7 th 1992 sebagaimana diubah dengan UU No 10 th 1998 tentang Perbankan. 